\title{
Analisis Sebaran Butiran Agregat Tanah, Sebaran Butir Primer TANAh, dan PERmeabilitas Tanah PAda PABRIK TEH
}

\author{
Irina Mei Risca Pratama ${ }^{1)}$, Ian Yulianti ${ }^{2)}$, dan Masturi ${ }^{3)}$ \\ 1, 2, 3) Prodi Pendidikan Fisika Program Pascasarjana UNNES \\ 1) E-mail: mayicha8@gmail.com
}

\begin{abstract}
Abstrak. Proses pembentukan tanah dimulai dari hasil pelapukan batuan induk (regolit) menjadi bahan induk tanah, diikuti oleh proses pencampuran bahan organik yaitu sisa-sisa tumbuhan yang dilapuk oleh mikroorganisme dengan bahan mineral dipermukaan tanah, pembentukan struktur tanah, pemindahan bahan-bahan tanah dari bagian atas ke bagian bawah dan berbagai proses lain, sehingga apabila kita menggali lubang pada tanah maka akan terlihat lapisan-lapisan tanah yang berbeda sifat fisik, kimia, dan biologinya, lapisan-lapisan inilah yang disebut dengan horizon tanah yang terbentuk dari mineral anorganik akar. Tumbuhan teh merupakan salah satu sumber daya alam yang dihasilkan dari pengolahan pucuk (daun muda) tanaman teh, Produksi pengolahan teh hitam di PT. Pagilaran menggunakan sistem pengolahan orthodox rotorvane. Pembuangan limbah teh yang telah diproduksi dalam PT.Pagilaran beruba cairan yang dibuang didalam tanah. Penelitian ini bermaksud mengkaji sebaran butiran agregat tanah yang dihasilkan adalah tanah berpasir dengan presentasi sebesar 59,34\%, sebaran butir primer tanah dengan presentase lempung dan lanau sebesar 40,66\%, pasir 59,34\%, dan kerikil 0,00\% karena ukuran butiran tidak lengkap dan hal itu menyebabkan butiran-butiran yang ada tidak saling mengisi dan menyebabkan adanya rongga, dan permeabilitas tanah tersebut termasuk dalam tanah pasir kelanauan hasil pembuangan pengolahan teh di PT.Pagilaran.
\end{abstract}

Kata Kunci: Tanah, Sebaran Butiran Agregat Tanah,Sebaran Primer tanah, Permeabilitas Tanah

\section{Pendahuluan}

Tanah memiliki arti yang sangat penting bagi setiap individu dalam masyarakat. Tanah terbentuk dari partikel pecahan batuan yang telah diubah oleh proses kimia dan lingkungan yang meliputi pelapukan dan erosi . Proses pembentukan tanah dimulai dari hasil pelapukan batuan induk (regolit) menjadi bahan induk tanah, diikuti oleh proses pencampuran bahan organik yaitu sisa-sisa tumbuhan yang dilapuk oleh mikroorganisme dengan bahan mineral dipermukaan tanah, pembentukan struktur tanah, pemindahan bahan-bahan tanah dari bagian atas ke bagian bawah dan berbagai proses lain, sehingga apabila kita menggali lubang pada tanah maka akan terlihat lapisan-lapisan tanah yang berbeda sifat fisik, kimia, dan biologinya, lapisan-lapisan inilah yang disebut dengan horizon tanah yang terbentuk dari mineral anorganik akar. Susunan horizon tanah tersebut biasa disebut Profil Tanah. Tekstur, struktur dan konsistensi tanah merupakan beberapa komponen yang penting dalam tanah sehingga pempengaruhi pertumbuhan dari tumbuhan [1].

Tumbuhan teh merupakan salah satu sumber daya alam yang dihasilkan dari pengolahan pucuk (daun muda) tanaman teh, Produksi pengolahan teh hitam di PT. Pagilaran menggunakan sistem pengolahan orthodox rotorvane. Sistem ini digunakan untuk memperoleh partikel bubuk teh yang berukuran kecil, sesuai dengan perkembangan pasar. Teh hitam produksi PT. Pagilaran sebagian besar diekspor ke luar negeri. Pembuangan limbah teh yang telah diproduksi dalam PT.Pagilaran beruba cairan yang dibuang didalam tanah. Penelitian ini bermaksud mengkaji tekstur, struktur dan permeabilitas tanah [3] hasil pembuangan pengolahan teh di PT.Pagilaran.

\section{METODE}

\section{A. Rancangan Penelitian}

Dalam penelitian ini peneliti melakukan analisis tanah yang didaerah pembuangan limbah pabrik teh, tentang sebaran butiran agregat tanah, sebaran butir primer tanah, dan permeabilitas tanah pada pabrik teh yang berada di Kabupaten Batang. Dengan menggunakan 2 sampel yang diambil berdasarkan jarak dari pembuangan limbah dari pabrik teh tersebut dengan melihat pada sebaran agregat tanah dilihat bagaimana struktur tanah tersebut yang meliputi lempung, lanau, pasir dan kerikil. Dalam sebaran butir primer tanah dibahas tentang kelas tekstur pada tanah yaitu tanah bertekstur kasar, tanah bertekstur halus dan tanah bertekstur sedang. Dan untuk permeabilitas tanah untuk menganalisis daya serap air dalam tanah dengan menggunakan alat hidrolik. 


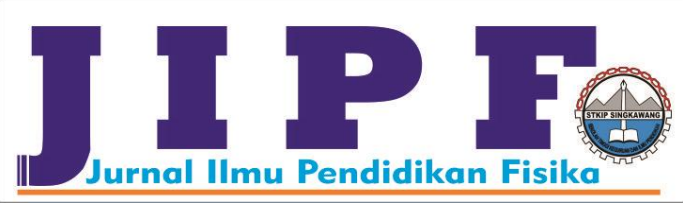

\section{B. Prosedur Penelitian}

Proses analisis pada sebaran butiran tanah menggunakan alat pengayak ( $40 \mathrm{~mm}, 60 \mathrm{~mm}, 80 \mathrm{~mm}, 140 \mathrm{~mm}$, dan $200 \mathrm{~mm}$ ) sehingga didapatkan sebaran butiran agregat tanah atau struktur tanah yang berupa lempung, lanau, pasir dan kerikil. Sebaran primer butiran tanah atau tekstur tanah dilihat apakah tanah tersebut termasuk dalam tekstur tanah kasar, halus dan sedang. Analisis untuk permeabilitas tanah untuk menganalisis daya serap air dalam tanah dengan menggunakan alat hidrolik. Dari kedua sampel tersebut kemudian dianalisis hasil dari masing-masing data yang diperoleh menggunakan Mc.Excel.

\section{HASIL DAN PEMBAHASAN}

\section{A. Sebaran Butiran Agregat Tanah}

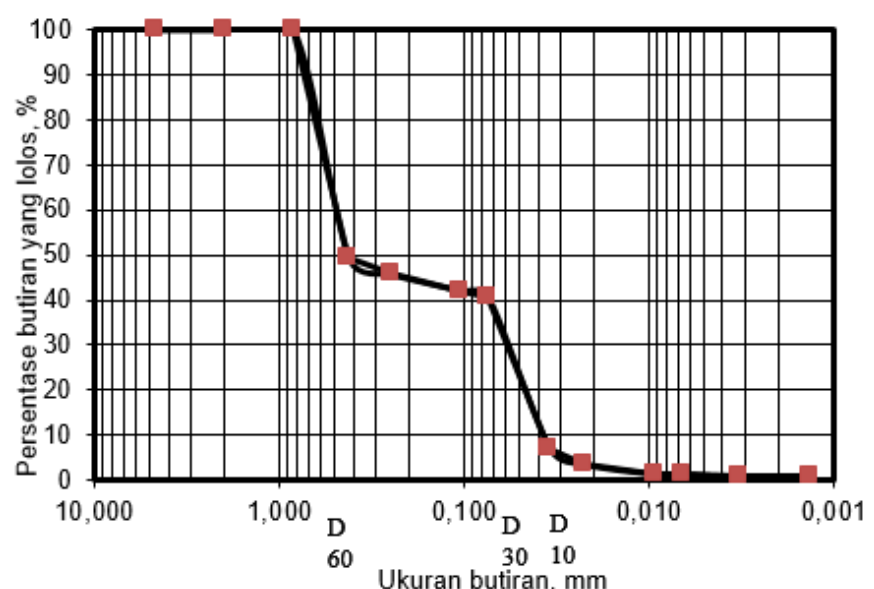

Gambar 1 Distribusi butiran tanah pada jarak $0 \mathrm{~m}$

Dilihat dari data yang ada maka sebaran agregat butiran tanah yang dihasilkan bahwa tanah tersebut termasuk tanah berpasir dengan $0,075<\mathrm{D}<4,75 \mathrm{~mm}$. Tanah bertekstur pasir yaitu tanah dengan kandungan pasir $>70 \%$, prositasnya rendah $35 \%$ keemampuan menyimpan air dan hara tanaman cukup.

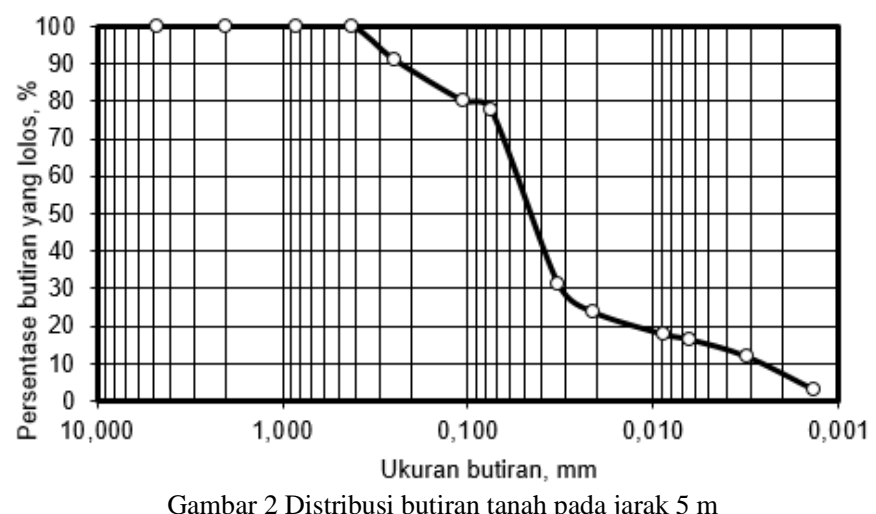

Dilihat dari data yang ada maka sebaran agregat butiran tanah pada jarak $5 \mathrm{~m}$ dari tempat pembuangan limbah yang dihasilkan bahwa tanah tersebut termasuk tanah lanau dengan $0,002<\mathrm{D}<0,075 \mathrm{~mm}$. Tanah bertekstur lanau yaitu
Jurnal Ilmu Pendidikan Fisika

Volume 2 Number 1 month March 2017. Page 7-9 p-ISSN: 2477-5959 e-ISSN: 2477-8451

tanah dengan kemampuan menyimpan air dan hara tanaman tinggi. Air yang diserap dengan energi yang tinggi.

Dari grafik yang telah terlihat diatas bahwa struktur tanah ini dengan presentase lempung dan lanau sebesar 40,66\%, pasir 59,34\%, dan kerikil 0,00\%. Dari grafik analisa butiran tanah di atas, grafik dibandingkan dengan [2] gambar bentukbentuk kurva distribusi ukuran partikel, maka tanah yang dijadikan sampel prakikum tergolong tanah dengan gradasi buruk (poor graded) [4] dimana ukuran butiran tidak lengkap dan hal itu menyebabkan butiran-butiran yang ada tidak saling mengisi dan menyebabkan adanya rongga.

\section{B. Sebaran Butiran Tanah Primer}

TABLE I

SISTEM KLASIFIKASI UNIFIED PADA JARAK $0 \mathrm{M}$

\begin{tabular}{cc}
\hline LEMPUNG $\quad \mathrm{D}<0.002 \mathrm{~mm}$ & $40.66 \%$ \\
LANAU $\quad 0.002<\mathrm{D}<0.075 \mathrm{~mm}$ & \\
\hline PASIR $\quad 0.075<\mathrm{D}<4.75 \mathrm{~mm}$ & $59.34 \%$ \\
\hline KERIKIL $\quad 4.75<\mathrm{D}<75 \mathrm{~mm}$ & $0.00 \%$ \\
\hline
\end{tabular}

Dari tabel yang telah terlihat diatas bahwa struktur tanah ini dengan presentase lempung dan lanau sebesar 40,66\%, pasir $59,34 \%$, dan kerikil $0,00 \%$. Dari grafik analisa butiran primer tanah di atas, grafik dibandingkan dengan [2] gambar bentukbentuk kurva distribusi ukuran partikel, maka tanah yang dijadikan sampel prakikum tergolong tanah dengan gradasi buruk (poor graded) [4] dimana ukuran butiran tidak lengkap dan hal itu menyebabkan butiran-butiran yang ada tidak saling mengisi dan menyebabkan adanya rongga.

TABLE 2

SISTEM KLASIFIKASI UNIFIED PADA JARAK $5 \mathrm{M}$

\begin{tabular}{|c|c|}
\hline LEMPUNG $\mathrm{D}<0.002 \mathrm{~mm}$ & $77.91 \%$ \\
\hline LANAU $0.002<D<0.075 \mathrm{~mm}$ & \\
\hline PASIR $\quad 0.075<D<4.75 \mathrm{~mm}$ & $22.09 \%$ \\
\hline KERIKIL $4.75<D<75 \mathrm{~mm}$ & $0.00 \%$ \\
\hline
\end{tabular}

Tabel yang telah terlihat diatas bahwa struktur tanah ini dengan presentase lempung dan lanau sebesar $77,91 \%$, pasir $22,09 \%$, dan kerikil 0,00\%. Dari grafik analisa butiran primer tanah di atas, grafik dibandingkan dengan [2] gambar bentukbentuk kurva distribusi ukuran partikel, maka tanah yang dijadikan sampel prakikum tergolong tanah dengan gradasi baik (good graded) [4] dimana ukuran butiran lengkap dan hal itu menyebabkan butiran-butiran yang ada saling mengisi dan padat.

\section{Permeabilitas Tanah}

Permeabilitas adalah cepat lambatnya air merembes atau masuk ke dalam tanah baik melalui pori makro maupun mikro baik kearah horizontal maupun vertikal. Didapatkan hasil dari pengujian tanah pada jarak $5 \mathrm{~m}$ dari tempat pembuangan 
tersebut adalah $0,0004488173 \mathrm{~cm} /$ detik. Dari hasil tersebut bisa dikatakan bahwa jenis tanahnya termasuk pasir kelanauan yang koefisien permeabilitas 0,002 sampe 0,0002 (cm/detik). Pada jarak $0 \mathrm{~m}$ dari tempat pembuangan didapatkan koefisien permeabilitas tanahnya sebesar $0,00007198 \mathrm{~cm} /$ detik termasuk dalam tanah lanau, yang koefisien permeabilitasnya sebesar $5 \times 10^{-4}$ sampai $10^{-5}(\mathrm{~cm} /$ detik $)$.

\section{KESIMPULAN}

\section{A. Simpulan}

Dari data diatas dapat disimpulkan bahwa struktur tanah dalam lahan pembuangan limbah teh tersebut termasuk buruk dimana ukuran butiran tidak lengkap dan hal itu menyebabkan butiran-butiran yang ada tidak saling mengisi dan menyebabkan adanya rongga. Untuk sebaran butiran primer tanah/ tekstur tanah termasuk dalam danah berpasir dan permeabilitas dari tanah tersebut sebesar $0,00007198 \mathrm{~cm} /$ detik sehingga termasuk pasir kelanauan.

\section{B. Saran}

Dalam penelitian ini masih banyak kekurangan dan diharapkan mampu untuk rujukan penelitian selanjutnya. Pengambilan sampel yang lebih variasi untuk menentukan lebih lanjut akan perbedaan ataupun pengaruh dari limbah tersebut.

\section{DAFTAR PUSTAKA}

[1] Anonim 2008. Tanah Pertanian: http//academia.edu.681-tanah-pertanian.(diakses 14 Desember2014).Anonym,2009.StrukturTanah.http://dseli pka.blogspot.com/2009/08/struktur-tanah-638html.(Diakses 6 Desember 2014)

[2] Hardjowigeno, S. 1993. Klasisikasi Tanah Dan Pedogenesis. Akademika Resindo: jakarta

[3] Madjid, Abdul. 2009. Dasar-Dasar Ilmu Tanah.Bahan Kuliah Fakultas Pertanian. Universitas Gajah Mada: Yogyakarta.

[4] Notohadiprawoto. 1998. Tanah Dan Lingkungan. Universitas Gadjah Mada: Yogyakarta. 